Originally published in: Public Archaeology 6(4), 2007, pp. 203-226.

\title{
Making things public Archaeologies of the Spanish Civil War
}

\author{
Alfredo González-Ruibal
}

\begin{abstract}
.
The archaeology of recent traumatic events, such as genocides, mass political killings and armed conflict, is inevitably controversial. This is also the case of the Spanish Civil War (1936-1939), where the incipient archaeology of the confrontation is marked by bitter debates: Should this conflicting past be remembered or forgotten? Which version of the past is it going to be remembered? What are the best politics of memory for a healthy democracy? The archaeologies of the war face manifold problems: the lack of interest in academia, which fosters amateurism; the great divide between public and scientific practice; the narrow perspectives of some undertakings; the lack of coordination among practitioners, and the threats to the material remains of the war. An integrated archaeology of the conflict, which helps to make things public, is defended here.
\end{abstract}

Keywords.

Archaeology of the contemporary past. War. Fascism. Material culture.

\section{INTRODUCTION: A NON-ABSENT WAR}

A British journalist, Giles Tremlett (2006: 73), recently noticed "the immense contrast between Spain's attitude to those who tortured, killed or repressed in Franco's name and those who did the same elsewhere". Spanish judges and activists tried to prosecute Pinochet in 1999 for his crimes against humanity as the dictator of Chile. Their efforts were backed by millions of Spaniards. However, as Tremlett notes, when it comes to their own recent past, Spanish people seem reluctant to excavate conflicting memories. Bruno Latour (2005) writes that "Each object gathers around itself a different assembly of relevant parties. Each object triggers new occasions to passionately differ and dispute. Each object may also offer new ways of achieving closure without having to agree on much else." This is true in the case of the material evidence of the Spanish Civil War: the disclosure of war objects-bones, prisons or bunkers-provide an occasion for fierce disputes that go well beyond disagreements on historical matters and profoundly affect the way in which democracy is played out in the present. With Latour, I would argue that war objects may also offer new ways of achieving closure. Yet for 
arriving to that, we need to make them public first-we have to remember in order to forget - and this is exactly where problems begin.

The Spanish Civil War started on $18^{\text {th }}$ July 1936 with a military coup led by General Francisco Franco and other right-wing officers (cf. Thomas 2001; Beevor 2006). Spain was governed at that moment by the Frente Popular ("Popular Front"), a coalition of left-wing parties that was democratically elected six months before. The country had been ruled along democratic lines since 1931, when King Alfonso XIII went into exile after municipal elections that gave an ample majority to the Republican parties - for the history of the Republic see Payne (1993). In the years that followed the king's exile, the Republican governments issued a (left-leaning) constitution and several laws and decrees-legalizing free worship, free press, civil marriage, secular education, women's vote, nationalities' rights, land redistribution to poor peasants, etc - that collided with the ethics and privileges of the dominant classes, especially landlords, the Church and the military. At the same time, the parties of the extreme left (communists and, especially, anarchists) were impatient for further developments and achievements that benefited the impoverished underclasses. The tension between left and right produced a rarefied environment of violence, failed coups, and killings on both sides of the political spectrum.

The military uprising in 1936 was backed up by traditional sectors, such as the Catholic Church, monarchists and part of the military, but also by falangistas (fascists). The coup unleashed a bloody repression on both sides - the difference being that on the rebel or Nationalist side violence was officially sanctioned (especially infamous are General Queipo de Llano's fiery speeches from Seville's radio, encouraging the assassination of civilians and the rape of women), whereas the Republicans never granted legal status to murderous excesses and tried to curtail them: indiscriminate killings were condemned by important politicians, who were genuinely horrified (Macías and Silva, 2003: 131-133; Espinosa Maestre, 2006). However, around 50,000 people were killed on the Republican side, and many other suffered tortures and imprisonment. The mass killing by militiamen and exalted peasants of priests and some nuns $(6,845$ individuals) was one of the darkest episodes on the Republican side. The war soon attracted foreign interests. Given the passivity of democratic governmentsFrance, Britain and the US-and the veto that prevented both sides from purchasing weapons abroad, the Republic resorted to the Soviet Union, which poured military material, men, technical assistance and Stalinist agents into Republican Spain. 
Likewise, Franco was supported by Nazi Germany and Fascist Italy. This transformed the Spanish conflict into a precedent of the Second World War.

The war was eventually won by the Nationalists in April 1939, after the rebel army managed to keep a disparate array of conservative and totalitarian movements united. Francisco Franco took on the task of government and ruled as a dictator until his death in 1975. The decade comprised between 1939 and 1948 was the most violent and bloody of his dictatorship. Figures are not clear, but as many as 150,000 people could have been killed between the beginning of the war and 1948 by Franco's repressive forces and sympathizers (Juliá, 1999: 410). Many others were imprisoned for life or condemned to forced labor and thousands died in the appalling circumstances of imprisonment (see Juliá, 1999). General Franco disregarded any proposal of healing war wounds, fostered the construction of monuments to his fallen and condemned his dead enemies to oblivion and their relatives to daily humiliation. Every church in Spain was decorated with enormous crosses and with each and every name of those fallen in the Cruzada Nacional ("National Crusade") against "Red Spain". In those places where leftist militiamen had committed atrocities, such as the places of mass execution of Paracuellos and Aravaca (Madrid), memorials were built and ceremonies celebrated every year. Streets, squares and towns were renamed after victorious generals and fascist martyrs.

After Franco's dead in 1975, Spain started its march towards democracy, with the help of Franco's appointed monarch, Juan Carlos I. Some initial attempts to revise the past, including early exhumations of people that were executed during or after the war, were cut short, however, by the failed military coup of 1981 (Silva and Macías, 2003: 122). The democratic transition sanctioned amnesty and amnesia (Reig Tapia, 1999: 352)—made legal by a decree in 1978 that exonerated all crimes committed during Franco's rule-with the purported goal of preventing a potential relapse into civil confrontation.

For two decades, the Spanish transition was considered exemplary, as it was carried out without blood-spilling. Nonetheless, from the early 1990s onwards, several other political models have been made available: the soft transition from communist to democratic regimes in many Eastern European countries (such as the Velvet Revolution in Czechoslovakia), the end of Apartheid in South Africa (Boraine 2001), and the rising of democracy in Latin America. Most of these transitions have taken place without slaughter and, what is also important, without amnesia. This has proved that forgetting 
is not necessarily a prerequisite for peace, even in those cases where war and dictatorship are extremely close to us in time. Furthermore, it is widely believed now that a sound democracy can only be built over the continuous revisiting and debating of the past and that it is only possible to heal trauma by constructing collective, shared narratives about that trauma, never by imposing oblivion (Alexander et al., 2004).

Why is the veil of silence over the war felt as no longer admissible by many Spaniards? Public debate about the war has been dormant for decades but it has emerged vigorously since 2000, when the exhumations of the victims of Franco were resumed (Silva and Macías, 2003). There is a new generation of Spaniards who do not feel compromised by the war and do not carry the burden of guilt: the grand-children of those who fought or were killed during the war. With the change of government after the elections of March 2004, the Socialist Party now in power has undertaken a more committed policy toward the memory of war and Francoism, which has been fundamental in sparking debate. The keystone is the controversial Law for the Recovery of Historical Memory (Espinosa Maestre, 2006), deemed too timid by some and responsible for opening war wounds by others. At any rate, the current situation proves that the war was never gone: it was a non-absent past: "a past that haunts like a phantom and therefore cannot be so easily controlled or subject to a finite interpretation. It is occupied by 'ghostly artifacts' or places that undermine our sense of the familiar and threaten our sense of safety" (Domanska 2005: 405). Meaningfully, objects are often in the origin of current controversies about the war. The bones of the killed, the buildings and properties of the vanquished seized by the victors, and the documents stolen by Franco's troops and kept in the Civil War Archive of Salamanca (Valdeón Baruque 2004) are some of things that spark debate in Spain today. The case of the Civil War Archive is a good example of the thing as gathering, the original meaning of the word: "the issue that brings people together because it divides them" (Latour, 2005, his italics). The debate is about documents-as-things: about property, location and collective ownership of historical artifacts, not about what these documents say.

It is not strange that almost 70 years and three generations must have passed since the beginning of the Civil War so that people can start revisiting the past and claiming for justice. The savage repression and the criminalization of dissent have created a difficult social environment for democratic culture: General Mola, one of the leading officers backing the coup, said that "it is necessary to spread an atmosphere of terror. We have to create an impression of mastery" (Beevor, 2001: 77). This led to a 
durable atmosphere of silence after the war. The time should be ripe now for an atmosphere of democracy (Latour 2005). This new atmosphere, however, does not only allow liberal voices to be heard, but also reactionary ones: an extreme-right revisionist literature is forcefully emerging today in Spain—see critique in Reig Tápia (1999). Revisionists minimize the extent of Francoist repression and criticize any attempt to recover the memory of the vanquished as a communist plot. Nonetheless, these visions are not only applauded by the extreme-right, but also by many people who have more moderate political views and simply feel uneasy with the return of Civil War ghosts. Revisionists, then, cannot be simply ignored as marginal aberrations-like Neo-nazi propagandists in Germany.

In what follows, I will outline the elusive archaeology of the Spanish War, adumbrate its main political and scientific problems and propose new venues of research that may encourage debate in democracy.

\section{A FORGOTTEN LEGACY}

The archaeology of the Spanish Civil War is achieving international recognition thanks to the exhumations of people killed during and after the war (Elkin 2006; Ferrándiz 2006; Renshaw 2007). However this necessary and praiseworthy undertaking - the most relevant in personal and political terms-obscures the importance of the war heritage at large, both from a historical and a political point of view.

During the peak of the war, the frontline occupied around 2,000 kilometers, from the Pyrenees to the Mediterranean coast in Andalusia (Thomas, 1976: 542) (FIG. 1). This is more than twice the length of the whole Western Front during the First World War (ca. $750 \mathrm{~km}$ ). The conflict was characterized by a stable line in many areas: some of the greatest battles ended in virtual stalemate (such as Brunete, Guadalajara or Jarama), almost without any territorial gain or loss. In many places, the remains of trenches and fortifications are astonishingly well preserved, because the front occupied public lands that could not be developed or marginal, unproductive areas (FIG. 2). Despite this impressive and pervasive material legacy, most of the remains have gone unnoticed until very recently: they are socially invisible-as opposed to the remains of the World Wars in Britain (Schofield, 2005), France and Belgium (Saunders, 2001; Price, 2005) — and, therefore, they are useless as a political lesson for the Spanish citizens (Santacana, 2004). The problems of these archaeological sites are manifold: 1) they usually lack official recognition, being too recent for the Spanish legislation, and 
they are easy prey for construction works and looters; 2) academic archaeologists in Spain have traditionally despised the post-Roman archaeological heritage as "not old enough" or too abundant in documentary sources to be worth exploring archaeologically; 3) the remains belong to an uneasy past that many prefer buried or vanished. The third point will be dealt with in the next section. I will address now the first two problems.

Unlike heritage legislation in the UK and the US, Spanish laws do not consider as archaeological heritage any remains that are less than 100 years old. In the case of fortifications, castles, towers and other military architecture protection affects only those structures that are at least 200 years old (Pérez-Juez et al., 2004: 177-78). This leaves without legal recognition all remains from the Spanish Civil War. Nonetheless, the law has been interpreted generously by heritage managers and public administrators and many modern sites are actually included in archaeological inventories, although cataloguing or not war sites still depends somewhat on the archaeologists' will, during the survey and characterization of the remains. On the other hand, some prominent places have enjoyed special protection granted by specifically issued decrees - Bien de Interés Cultural - BIC ("Property of Cultural Interest"). This is the case of the ruins of Corbera d'Ebre, a village razed during the Battle of the Ebro (1938), a BIC since 1993 (Besolí et al., 2002: 14). Some destroyed villages were already protected as war monuments during Franco's time - the most famous example is Belchite (Aragon) who was aware of the political usefulness of mobilizing ruins for propaganda purposes. Specific actions, however, do not help to defend this heritage from its two main enemies: urban development and looters.

The increment of public works and especially a chaotic urbanism, fraught with corruption and mismanagement, is menacing the Civil War heritage, most especially in Madrid and neighboring areas, but also in Barcelona (Besolí, 2004: 200-201). The fragility and ephemeral nature of the material remains from the contemporary past has been emphasized by several authors (e.g. Klausmeier and Schmidt, 2004; Schofield, 2005: 82-86). Despite the sturdy appearance of concrete fortifications, the material legacy of conflicts can disappear very fast, and with it important political lessons for the future are irremediably lost. Many remains from the Spanish Civil War have already disappeared or are decaying without proper recording: a good example is the prison of Carabanchel, which was built in Madrid in 1940 to incarcerate thousands of political 
prisoners and was abandoned and left to decay in 1998 (FIG. 3). The fate of the ruins is uncertain, but some local associations want at least a part of the building preserved as a historical monument.

At the same time, it has been the threats to these sites that have led to its recovery: this is what occurred in the Republican fort of Casas de Murcia (Madrid), the first Spanish Civil War site ever excavated (Morín de Pablos, 2002) and the fortifications of Seseña and Bótox (Toledo), catalogued by a team of contract archaeologists (López et al., 2005). Other fortifications and trenches in Madrid have been excavated recently during rescue works but the reports are likely to remain unpublished.

The other great danger to the heritage of the Spanish Civil War is looters (Santacana, 2004: 175). Lacking any legal recognition, many sites have been (and still are) thoroughly looted by war enthusiasts - a problem that is shared by similar sites elsewhere (Price, 2005; Sutherland and Holst, 2005: 17) —and collectors and amateurs discuss their findings in the Internet with impunity. ${ }^{1}$ However, rather than simply bemoaning these aggressions, we should try to involve looters, who are often wellmeaning and enthusiastic, in the recovery and preservation of the Spanish Civil War heritage, as done in France with the remains from the First World War (Saunders, 2002: 105). In fact, the problems in Spain are very similar to that of the World Wars: the indifference of academia has favored the intervention of outsiders with different personal agendas and interests (Laffin, 1993; Saunders, 2002: 103-106; Price, 2005), including economic ones. Collaboration between individuals, collectives, contract archaeologists and research institution is badly needed.

Unfortunately, Spanish academia traditionally looks down on the archaeology of all those periods after Late Antiquity. The number of medieval and post-medieval archaeologists working in universities or research councils in Spain is very scant, compared to prehistorians and Roman archaeologists. One of the reasons that explain the academic oblivion that plagues much recent heritage is the belief that texts are plentiful and the study of material remains has little to offer. This reasoning, widely deconstructed in the Anglo-Saxon tradition (e.g. Tarlow and West, 1999; Buchli and Lucas, 2001) and in Latin America (Funari, 1997), can be understood in the context of Mediterranean archaeology, where the pre- $16^{\text {th }}$ century past is extremely rich in monuments, artifacts and sites, and determines to a great extent the cultural imagination and identity of modern populations. Given the prevalence of these visions, it is not 
strange that the research, valuation and protection of the archaeological heritage of the Spanish Civil War have often been left in the hands of professionals working in cultural resource management, who have other priorities rather than conducting research and divulging their work; local institutions-counties and town councils; and, mainly, amateurs. Initiatives for the recovery and exhibition of war remains usually come from civic associations that skip academia altogether (Besolí et al., 2002: 14).

Nonetheless, there have been some remarkable heritage projects coordinated by Catalonian universities and research institutions, including the Universitat de Barcelona, Universitat Autónoma de Barcelona, Universitat de Lleida and Institut Catalá d'Arqueologia Clàssica - Tarragona (Castell et al., 2000; Besolí et al., 2002; Gassiot, 2005; Mir et al., 2006). Some of these projects have met with resistance from local authorities, such as the failed attempts to excavate a mass grave in Albinyana (Íñiguez and Santacana 2003), or with lack of political support (Besolí et al. 2002: 15; Gassiot 2005: 103), although the situation seems to be gradually changing for good (Mir et al. 2006). In other parts of Spain, there exists a growing number of archaeologists from universities collaborating in the exhumation of tombs (e.g. the Universities of Valladolid and Málaga) (Junquera, 2006), but this activity is apparently regarded as an altruistic, public task, rather than as a scientific undertaking equal to the excavation and documentation of prehistoric or classical remains. Contrary to what happens in Latin America, "public" and "scientific" archaeologies seem to be often conceived as two different realms. The works undertaken by archaeologists from the Universitat Autónoma de Barcelona are among the few to make a research topic of the Civil War (Gassiot, 2005, Gassiot et al., 2006).

The reluctance to engage with the material remains of the conflict by academics has not to be related to the political position of Spanish archaeologists: local researchers have dissected with relish the troubled history of the discipline during Franco's time, the manipulation of archaeological knowledge to please the imperial dreams of the new regime, and the sinister connections between archaeology and politics (Díaz-Andreu, 1997; Ruiz Zapatero and Álvarez-Sanchís, 1998; Ruiz et al., 2002; Wulff and Álvarez, 2003). This proves that the lack of scientific engagement with the archaeological remains of the recent past is not always a matter of politics, but rather an epistemic issue: what is deemed worth of archaeological scrutiny and what is not. 


\section{THE RETURN OF THE REPRESSED: SURVEYING AND EXCAVATING THE WAR}

An exploration of the archaeological bibliography of the Spanish Civil War's bibliography reveals that the studies and projects existing to date are usually disconnected from other similar works, have a narrow scope, are seldom directed by professional archaeologists and are divulged in obscure journals, local books with very limited circulation, newspapers, leaflets, and unobtainable proceedings-when they are published at all. This certainly goes against the necessity to make things public and does no favor to the general interest in those matters: an interest reflected in an ever growing corpus of popular books on the conflict. Different kinds of archaeological studies on the conflict are currently available: they have to do, respectively, with the documentation and divulgation of military architecture, the excavation of battlefields, and the exhumation of mass graves. Each of these archaeological practices is carried out by different collectives: associations of military history amateurs and town councils, contract archaeologists, and victims' organizations with the participation of forensic scientists and voluntary archaeologists.

The documentation of military structures (FIG. 4), as it does not require an official permit, has been carried out by associations and private individuals, who sometimes divulge their findings in the Internet ${ }^{2}$. Several "memory trails" have been established in different parts of Spain, sponsored by grassroots associations and municipalities. This is the case of COMEBE, Consorcio para la Musealización de Espacios de la Batalla del Ebro, in Catalonia ${ }^{3}$, which is interested in the preservation of the spaces affected by the Battle of the Ebro (1938). Catalonia is one of the most active regions in recovering and revaluing the Civil War heritage with several projects under way (Romero, 2001, 2003), some of them in collaboration with other European countries. In Asturias, ARAMA $36 / 37^{4}$, Asociación para la Recuperación de la Arquitectura Militar Asturiana 1936/1937, tries to raise public awareness of the relevance of the Civil War heritage in the region. In Madrid, several municipalities, such as Aranjuez ${ }^{5}$ and Brunete ${ }^{6}$ provide information about the Civil War sites within their boundaries. The remains of the Battle of the Jarama in Madrid are being inventoried by a non-professional association, GEFREMA, Grupo de Estudios del Frente de Madrid ${ }^{7}$, under the auspices—and with the funding of-a town council (Rivas). GEFREMA has been promoting the recovery and documentation of war remains in the region since 2003. They have self-published three brief guides so far and 
organize frequent toured visits to battlefields. Madrid was one of the first regions where the Civil War heritage was defined as such (again, not by archaeologists), with an exhibition and a book in 1987 (Montero Barrado, 1987, 2001). In Valencia, different municipalities are sponsoring routes through war scenarios (Calabuig, 2006) and the same happens in the Pyrenees (Visa, 2006). Where councils are involved, the main issue is bringing tourists to the area and an unlikely apolitical stance is consistently adopted.

During the last years a few museums have been opened in military structures: two good examples are the air raid shelters from Cartagena (Murcia) ${ }^{8}$ and Almería (Andalusia) ${ }^{9}$. Air raid shelters have received considerable attention in recent times (Besolí, 2004; Besolí et al., 2006; Piñera, 2006) and they are among the first examples of military buildings to have been musealized and opened to the public. In Barcelona alone, over 1,400 refuges were built during the conflict, both by local authorities and private individuals (Besolí, 2004: 185). Although the presence of professional archaeologists is limited, contract archaeologists have recently started to document military architecture from the Civil War and to propose typologies (Díaz Díaz, 2005).

Several battlefields have been excavated since 2000 by contract archaeologists, mainly in Madrid, Asturias, Aragon and Catalonia, but most of them remain unpublished. During the excavation of prehistoric and Roman sites Civil War vestiges have sometimes turned up (Romero, 2003: 92; Gassiot, 2005: 103). However, they have been documented only recently and they rarely make it to the final publication. With the new public awareness toward this kind of heritage - echoed by the increasing presence of news regarding Civil War remains in major Spanish newspapers (such as El País) the situation will probably change. One of the first sites to be excavated and published was the aforementioned Casas de Murcia (Madrid), a Republican fort built over an Iron Age settlement (Morín et al., 2002, Morín, 2003; Pérez-Juez, 2002, 2004). The place was fortified during the rebel offensive of the river Jarama, between November 1936 and February 1937. The excavation yielded a system of trenches with machine-gun nests, sniper pits, ammunition depots and a dugout used as a command post (FIG. 5). Inkpots, bottles of medicines and vitamins, a canteen with two bullet holes, a belt buckle, rifle and machine gun ammunition have been found in the site, among other things.

Other trenches have been excavated in 2005 and 2006, although publications are not yet available. In that of the "Orwell Route" in Los Monegros (Aragon) ${ }^{10}$, the archaeologist in charge, José Ignacio Lorenzo, has reported the discovery of numerous 
artifacts belonging to Republican fighters, including wallets, scabbards, shoes, harnesses, boots and coffee cups (Boletín Fundación Andreu Nin, 2006). There have been some remarkable findings, such as champagne bottles, probably confiscated in a road control, and lamps made with sardine tin cans. The restoration of these trenches, however, raises issues of authenticity and the commodification of suffering that always affect recent sites (Olivier, 2001). Another excavation in Civil War trenches has taken place in the Republican defenses of Oviedo (1937). Here, a concrete machine-gun nest was excavated that yielded several bullets, a flare shell casing, five hand-made grenades made by Republican industrial workers and two Czech grenade fuses (Álvarez Martín, 2006). The fortifications of Oviedo have made it to the news late in 2006 due to the construction of new highways around the city that would destroy Civil War structures. Interestingly, it was not archaeologists but the association ARAMA 36/37 that struck a warning note (Nicieza, 2006).

Excavations in trenches show the great potential of Spanish Civil War sites. As it is always the case with historical archaeology, artifacts help to delineate a differentor at least richer and more intimate-image of the war experience that immediately creates an emotional connection between past and present. It also shows a more banal, and at the same time terrible, image of the war, different from the often glorious one offered in history books (Sutherland and Holst, 2005: 4). The most relevant point about the excavation of Civil War remains is that something that was concealed or forgotten is now emerging, coming back to the surface. In this way it is challenging the dangerous "politics of disappearance" that characterize our times (Virilio and Lotringer, 1997). The archaeology of the recent past deals with spectral things from a non-absent past that are being made public and mobilized in current political debates about history, heritage and politics. This revelation is not to everybody's like. The uneasiness towards this unearthed past is all the more obvious in the case of mass graves.

Amateurs, municipal corporations and contract archaeologists claim to be apolitical: they are simply interested in studying and displaying what is left from the past. Such unlikely neutrality is not usually advocated by those who excavate graves, although their political positioning is expressed more or less strongly depending on the organization-the most overt political association being Foro por la Memoria, backed by the Communist Party (Barragán and Castro, 2004-2005; Ferrándiz, 2006). Until now, mass graves have understandably received the greatest attention by archaeologists, historians, anthropologists and the lay public alike, in Spain and beyond. Since this 
topic has been explored at length by other authors, I will devote less space to exhumations and refer to the extant bibliography-for summaries in English see Elkin (2006); Ferrándiz (2006); Tremlett (2006) and Renshaw (2007). Most excavations have been carried out by members of the Asociación para la Recuperación de la Memoria Histórica-Association for the Recovery of Historical Memory (ARMH), starting in 2000, and by Foro por la Memoria, starting in 2003 (Barragán and Castro, 2004-2005: 152). The ARMH collaborates with the Sociedad de Ciencias Aranzadi, a Basque academic institution which provides laboratories and forensic scientists led by Francisco Etxeberria. Foro por la Memoria is helped by specialists from diverse Andalusian universities. From its beginnings, grassroots associations have improved the quality of their work and now excavations are conducted with high archaeological and forensic standards, including the use of the Harris Matrix, detailed maps with the identification of bones, artifacts and archaeological features, geophysical surveys and DNA analysis among other things (cf. Etxeberría, 2004; Etxeberría et al. n.d.; Barragán and Castro, 2004-2005) (FIG. 6). Foro por la Memoria has made public a detailed protocol of intervention, available in their webpage. The results have been only occasionally published as full forensic-archaeological reports, although more and more interventions are being divulged in journals and academic venues (e.g. Barragán and Castro, 20042005; Fuentes 2005).

Around 900 corpses have already been recovered all over Spain-a very small percentage, however, of the total killed, frequently updated webpages with news and reports of exhumations are available ${ }^{11}$ and a successful book has been published (Silva and Macías, 2003). There are still hundreds of unexcavated graves all over the country. Many of them only have one to ten people, because murders were committed by local groups of fascists in the surroundings of their homes. However, in a few burials thousands of bodies are known to have been deposited. In Oviedo (Asturias), for example, the local mass grave hides 1,679 corpses (Silva and Macías, 2003: 167). The most appalling atrocities included the assassination of children, pregnant women and elderly: this is the case of Caudé's grave, containing 1,005 individuals, mostly civilians (Silva and Macías, 2003: 151-163) or the Sima de Jinámar (Canary Islands), used as a rubbish dump for a long time (Silva and Macías, 2003: 185-195). The details that have been appearing in the media have helped to stir up public debate (Ferrándiz, 2006) and the excavation and commemoration of the assassinated has taken place amid heated discussions. Thus, in Valencia, the right-wing council banned the installation of a 
commemorative plaque remembering the thousands anonymous people killed by Franco and buried in a mass grave in the city cemetery (Montaner, 2006). Other monuments and memorials have been defaced or destroyed.

Problems do not only arise between those who want to forget and those who want to remember, but also between those who choose different ways of remembering: for some, excavating the burials is an "erasure of genocide" and they prefer to promote "above-ground" commemorative and symbolic markers only (Ferrándiz, 2006: 9). A similar debate has marked Argentina's quest for justice (Crossland, 2000: 153-155). Amid pro-exhumers, disagreement does not lack either, in this case concerning methodology and mortuary rituals (Ferrándiz, 2006: 9). Besides, there exists disagreement about the final purpose of the exhumations. Foro por la Memoria adopts a more political stance: they ask for the complete annulment of Francoist justice and the legal, moral and economic reparation for the victims (Barragán and Castro, 2004-2005; Ferrándiz, 2006). Meaningfully, the fragmentation of opinion within the left echoes that of the Civil War, when a conflict between liberal republicans, communists and anarchists hampered war efforts and eventually gave the victory to Franco. Whereas few within the right question the necessity of amnesia openly, the left is continuously disagreeing over how to remember and render things public. The exposure of Civil War bodies, in any case, is acting as a powerful political catalyst and is showing that war wounds were not properly sutured. "The recent rapid emergence of ghosts of the Spanish Civil War"—writes Ferrándiz (2006: 10)—“who had lain for six decades under a shroud of silence, has thrown the country into an unexpected public debate exposing conflicting political cultures, not only between ideological groupings, but also between generations". Exhumations and reburials, however, also prove archaeology's ability to provide closure: many people live the experience of recovering the remains of their relatives as a relief, a cathartic experience that allows people to close an painful episode of their lives and move on. The question that remains is, should personal closure preclude further political struggle (for justice and reparation) or are both compatible? What is the social and political price of continuing or ending the struggle? (see Crossland [2000] for a similar debate in Argentina).

According to Bruno Latour (2005), there are many types of gatherings which are not political in the customary sense, but which bring a public together around things: churches, laboratories, marketplaces, museums. The archaeological sites of the Spanish Civil War are also a particular "parliament of things", that brings together objects, 
people and discourses. This is, however, a parliament that many want closed, dismembered or dissolved. For that reason, it is especially urgent to undertake an integrated archaeology of the conflict, an archaeology that truly challenges the prevalent politics of disappearance and concealment and shows to the public collectives and connections (of peoples, things, spaces and times), rather than fragments, for open discussion.

\section{TOWARDS AN INTEGRATED ARCHAEOLOGY OF THE SPANISH CIVIL WAR}

One way to work against concealment and oblivion is showing connections: between different places, artifacts and people and between different pasts and presentsrecomposing the Thing politic. From this point of view, an integrated archaeology of the Spanish Civil War has four main issues to take into account: landscape, process, material culture and memory.

The archaeologies of the war should work with whole landscapes and processes, as it has been proposed for other war scenarios (Schofield 2005). This means understanding the conflict as a far-reaching historical event that deeply-and materially-transformed the country and left lasting scars in the territory. We have to make these scars visible: make a familiar landscape unfamiliar, uncanny (Buchli and Lucas, 2001), and help people to see the traces of the past and to engage with their ordinary environments more critically. First, it is necessary to integrate the different remains of the frontline and its more conspicuous structures with the less obvious traces of the rearguard, in order to fully understand the daily lives of people under the sinister circumstances of a civil conflict: the bomb shelters, the cemeteries and roadsides where people were shot and anonymously buried, the weapons factories, the prisons and camps, the marks of shrapnel and bullets on buildings, the barracks where people suffered tortures and death. As archaeologists, we have to be able to conjure up through material culture the ambience of terror and insecurity that impregnated everything and became embodied in different landmarks of the urban fabric and the countryside. Whereas many of these places have been forgotten or transformed forever, others still loom large, as terrible dystopias, in the collective memory of the people who live around. As negative heritage (Meskell, 2002), Civil War sites are an uneasy legacy, difficult to deal with. Making these sites present again in public discourse, as places of memory, is a thorny activity-but necessary to buttress a truly democratic culture. The 
best way to mediate the intricacies of this past and landscape is through what some authors have called "topology" (Shanks, 2001: 293; Witmore, 2007). Topology maps networks of connections between disparate elements (the roadside, the trench, the prison) and avoids a stark division between past and present and between different pasts.

Along with the spatial extension of the battlefield, we have to make a temporal move, going beyond the three years of the armed confrontation and exploring the whole process of the conflict. After all, the state of war was only officially ended in 1948 and many mass graves belong to the post-war period (Silva and Macías, 2003). Furthermore, the war implied "painful changes in the social landscape, including internal and external migration, the uprooting of rural communities and industrialization at all costs" (PiSunyer 2006), all of which has left archaeological traces (González-Ruibal, 2005). The temporal extension of the battlefield involves, at a primary level, archaeological research on concentration and labor camps established after the war, on the new prisons, orphanages, schools and barracks - the whole new economy of punishment (Foucault 1975). Especially remarkable are the internment camps, which are a matter of growing concern among historians and journalists (Lafuente, 2002; Molinero et al., 2003; Núñez Díaz-Balart, 2004; Rodrigo, 2005). Around 180 concentration camps were established all over Spain (Rodrigo, 2005). Many reused previous buildings (bull rings, hospitals, military barracks, police headquarters) that eventually reverted to their original use. A few, however, have survived as archaeological relics: a good example is that of Bustarviejo (Madrid). It was established in 1944 for the construction of the MadridBurgos railway and abandoned in 1952 (Olaizola, 2006: 21-22). The whole landscape of repression has been remarkably well preserved, including the prisoner barracks, sentry boxes, stalls, warehouses, tool sheds, quarries and the colossal railway embankment and tunnels built by the convicts (FIG. 7).

The state of war was also maintained due to the activities of the maquis, the antiFrancoist guerrilla, which has been the object of some recent archaeological research (Díaz et al., 2005; Morín et al., 2006): the refuges of the maquis in mountainous areas and the graves where many of them were anonymously buried after being killed by Franco's repressive forces, are starting to be the documented archaeologically (Barragán and Castro, 2004-2005: 169-173).

Material culture is necessarily the locus of attention for archaeologists. It includes military architecture, trenches, campsites and all other elements in the frontline 
and the rearguard pointed out above, but also the impact of the new technologies of mass murder on a still fairly traditional society. The agency of things adopted a sinister cloak during the 1930s and 1940s: A prominent role was played not only by obviously lethal artifacts, such as bombers or tanks, but also by roads, telephones, cameras or the radio (Thomas, 1976: 1004). The role of material culture is especially remarkable in the "fascistization" of the country since the beginning of the war: the proliferation of monuments following the fashionable fascist trends of the period, of memorials and military cemeteries (Álvarez Martínez et al., 2006), the celebration of Catholicism by means of oversized crosses, memorial chapels and the revival of the CounterReformation style of the $16^{\text {th }}$ century (FIG. 8). In a few years, Spain went back several centuries to a dark period of knights and monks, as the dictator longed for young Spaniards to be. The buildings and monuments of Spain's Fascism have been scarcely explored (López Gómez, 1995; Álvarez Quintana, 1997), despite their historical interest and the obvious relations and (striking differences) with Nazi and Mussolinian architecture-which have received more attention (e.g. Jaskot, 2000; Pizzi, 2005).

The analysis of fascist material culture does not have to study monuments only. It has to excavate the mechanisms used in deploying power in everyday practice: a good example is the proliferation of public fountains with the symbol of Falange-a yoke and a bundle of arrows. A daily act became inscribed with a pervasive and obvious political sign: something as basic as fetching water for drinking or washing was granted and simultaneously surveilled by the omnipresent Spanish fascist party. Totalitarianism owes its name to the totality it affects: it is not restricted to the political arena, but it slithers down the most intimate and minute crevices of individual freedom. What I propose, then, is an archaeological exploration of Spanish fascism that goes beyond discourse and representation, grants material culture a more prominent role in our accounts of the past, explores the sensuousness of totalitarian power, and destabilizes the monumental landscapes of dictatorship.

Finally, with regard to the politics of memory, it is necessary to add more theoretical depth to the debate: "memory" is a buzzword used by both supporters and critics of revisiting the past. However, there is a certain lack of theoretical tools that help to orient the discussion (but see Bermejo Barrera, 1999, 2002; Gavilán, 2004; Ferrándiz, 2006). First, it would be rather more convenient to talk about social, public or collective memory (Connerton, 2006: 315), rather than about "historical memory", a concept profusely employed in Spain, despite its paradoxical nature (Gavilán, 2004): for 
most scholars, history and memory are actually opposed (e.g. Nora, 1984). Not surprisingly, memory and material traces have been studied in-depth in France (Nora, 1984) and Germany (Kosher, 2000), where troubling recent pasts have been haunting the present since the end of the Second World War (Connerton, 2006). Something similar should be expected in Spain. Nevertheless, whereas in France and Germany an acceptably common narrative, helped by pervasive democratic ethics, has been finally created-and similar processes are underway in the Eastern European countries (Connerton, 2006: 317), in Spain a large part of the population, including academics, still has a fairly positive view of Francoism. They do not want a different, bloody past to occupy their sanitized memories of the dictatorship. For them, bringing forward the material remains of the war and post-war periods helps to create a negative heritage that did not exist before.

Collective memories are consequently fragmented and in perpetual struggle: a shared idea of democracy destroyed by totalitarianism does not exist in Spain. Thus, the removal of an equestrian statue of General Franco in Madrid in 2005 produced a disproportionate controversy (Rodríguez, 2005). In an informal opinion poll carried out by the right-wing newspaper El Mundo, 54\% out of 58,977 people that voted through the Internet were against the removal of Francoist monuments ${ }^{12}$. This includes directors of the Royal Academies of History and Fine Arts Gonzalo Anes and Ramón González de Amezua, who bemoaned what they saw as an attack to the past-the Spanish Royal Academies are known for supporting strongly reactionary views. The material exaltation of Nazism, Communism and Fascism has been (or is being) erased or reinterpreted, not without trauma and controversy, but usually with social consensus. What has been preserved, like some traces of the Berlin Wall (Klausmeier and Schmidt, 2004) is displayed as a repository of negative memory in the collective imaginary (Meskell, 2002), a cautionary tale from the past. The archaeological remains of Francoism are proving to be much difficult to deal with. The attitudes that advocate for the preservation of all the extant material remains of dictatorship without further interpretation show that a preservationist ethos is not inherently good, liberal or progressive (Holtorf, 2006).

Conservatives, including the main right-wing party in Spain (Partido Popular), are not against discussing history per se, but argue that it should be restricted to the academic arena and to specialists only. Archaeology destabilizes this undemocratic situation by making things public (Latour, 2005): unearthing corpses, displaying 
trenches, bunkers and prisons, showing the hollow material rhetoric that supported a despotic regime. Scholars and politicians can deny access to documents in archives or university libraries, but they cannot prevent people from going to the battlefields seeking bunkers and trenches or stop families digging up their dead. Conservatives are partially right: the monuments of the past do not have to be erased - not all, at least: they have a function to fulfill as negative heritage. They have to be re-read, re-worked and re-displayed using a new democratic discourse. What we need is "landscapes of countermemory", that emphasize contradictions, repressed pasts and "[keep] discourse open as a public sphere of challenge and counterchallenge" (Hall, 2006: 207). As Michael Shanks has pointed out, we, as archaeologists, work with what is left from the past (Shanks, 2001: 294; Shanks, 2004). We write accounts from fragments; we select plots and stories. This is not inventing (in the sense of falsifying) the past. Leaving Francoist monuments as we have inherited them, as if their triumphal message was the only possible reading of history, the true memory to be preserved, it certainly is.

According to Bruno Latour, politics might not be so much about opinion as about things — things made public (Latour, 2005, see also Shanks, 2004). Whisking away things, then, is negating politics. And negating politics, or restricting it to the chosen few, means totalitarianism. It comes as no surprise that General Franco said: "Follow my example, never do politics". Never make things public.

\section{CONCLUSION: EVIL WAS HERE}

The archaeology of the Spanish Civil War is about more than a fratricidal confrontation, Spain and the past. The conflict has produced almost as much bibliography (both local and international) as the Second World War (Paul Preston quoted in Reig Tapia, 1999: 320). It captured the world imagination in a troubled era and it became part of the social memory of the $20^{\text {th }}$ century. If the Great War was the first global war, the Spanish conflict should be considered the first globalized war: a local confrontation made global, both politically and materially. It transcended the frontiers to be regarded as a universal struggle between Totalitarianism and Democracy, Fascism and Revolution, Right and Left. It also produced at least as many archaeological remains as the Western Front during the First World War, and fostered one of the most brutal repressions in

Western Europe in the $20^{\text {th }}$ century, second only to the Nazi carnage. Tens of thousands of corpses still remain in unmarked graves all over the country. 
As it occurred with the archaeology of the World Wars, the incipient archaeology of the Spanish conflict has been characterized so far by the lack of coordination among practitioners, a narrow scope and a good degree of amateurism: some people excavate graves, others document bunkers and military architecture, others recover trenches and battlefields in general, still others monuments and memorials, and only a handful of archaeologists, mainly from Catalonia, have clearly defined research projects. Many of these works are only available as unpublished reports, newspaper articles, in obscure local journals or in the uncertain fate of Internet pages. Besides, the archaeology of the Civil War is severed from the archaeology of the pre-war and the post-war periods. It has been argued here that we cannot understand battlefields without exploring mass graves, military barracks, prisons and fascist architecture: we have to make sense of the materiality of whole warscapes and historical processes. In the era of total war and totalitarian regimes, it is totalities that have to be appraised.

Of course it is not amateurs investing their time and efforts in documenting war remains or professionals doing contract archaeology who are to blame for the quality of Civil War archaeology in Spain (just the opposite), but scholars working in universities and public institutions who do not pay heed to an obvious social request and, even worse, academics and politicians who consider that some things should not be made public. I have advocated here the encouragement of a collective, plural debate about the past using the material remains of that past. A plea for multiple voices, however, has often meant the neutralization of politics, by equating all opinions, respecting all voices alike, depoliticizing suffering and extending the status of victim indiscriminately. These are all symptoms of what Slavoj Žižek calls the "postpolitical”- - see discussion in Dean (2006: 114-125). The vision of democracy that is espoused here is in some senses akin to that defended by Žižek, and is opposed to the depoliticized logic of late capitalism. With the philosopher, I believe that politics-and democracy-involve division and exclusion. In this case, exclusion of extreme right positions, but also of those who deny others the right of bereavement and public reparation.

Exploring the Spanish Civil War is a must for archaeologists. It implies stepping down from the ivory tower of academic archaeology and entering a messy battle of troubled memories and conflicting interests. Archaeologists have a responsibility towards society and towards the murky and troubled heritage of recent history. The archaeology of the contemporary past can make things public, re-assemble the parliament of things and add a tangible, experiential dimension to our knowledge of 
history. And above all, it can make us remember that "evil was here" (Sontag, 2003), not so long ago, behind our own homes, beneath our very feet.

\section{ACKNOWLEDGEMENTS}

I would like to thank to the Asociación para la Recuperación de la Memoria Histórica and Emilio Silva for kindly providing permission to reproduce figure 6. I am grateful to Valentín Álvarez Martínez and David González Álvarez for providing information and articles about the archaeology of the Spanish Civil War in Asturias. I also thank Francisco Ferrándiz (CSIC, Madrid) for sending me his publications about the ethnography of exhumations. The research in the concentration camp of Bustarviejo is being carried out in collaboration with Álvaro Falquina Aparicio, Pedro Fermín Maguire, Carlos Marín Suárez, Alicia Quintero Maqua and Jorge Rolland Calvo. The study of the prison of Carabanchel is an initiative of Carmen Ortiz García and Cristina Sánchez Carretero (CSIC, Madrid), in which I have been invited to participate. Finally, I thank two anonymous referees for their valuable suggestions and criticisms.

\section{REFERENCES}

Alexander, J.C., Eyerman, R., Giesen, B., Smelser, N.J., and Sztompka, P. Cultural Trauma and Collective Identity. Berkeley, California University Press (2004).

Álvarez Martínez, V. Excavaciones en un nido de ametralladoras del cinturón republicano de Oviedo. Unpublished report, no 37/2000. Servicio de Patrimonio, Consejería de Cultura del Principado de Asturias (2006).

Álvarez Martínez, V., Éxposito Mangas, D. \& González Álvarez, D. El cementerio moro de Barcia: acercamiento a su estudio. I Congreso del Real Instituto de Estudios Asturianos (2006).

Álvarez Quintana, C. El compromiso del historiador de Arte con la arquitectura española en la etapa franquista: (1940-1975). Actas Simposio El historiador del arte, hoy. Soria, CEHA (1997) 133-142.

Barragán, D. and Castro, J.L. Arqueología de la justicia. Arqueología de las víctimas de la guerra civil española y de la represión franquista. Revista Atlántica Mediterránea de Arqueología Social 7 (2004-2005) 149-174.

Beevor, A. The Spanish Civil War. London, Penguin (2001) [1982].

Beevor, A. The battle for Spain: The Spanish Civil War 1936-1939. London, Weidenfeld \& Nicolson (2006). 
Bermejo Barrera, J.C. La historia, la memoria y el olvido. In: Bermejo Barrera, J.C. and P. Piedras Monroy: Genealogías de la historia. Ensayos de historia teórica III. Madrid, Akal (1999).

Bermejo Barrera, J.C. ¿Qué debo recordar? Los historiadores y la configuración de la memoria. Memoria y Civilización 5 (2002) 191-218.

Besolí, A. Los refugios antiáreos de Barcelona: pasado y presente de un patrimonio arcano. Ebre 382 (2004) 181-202.

Besolí, A., Hernández, F.X., Íñiguez, D., Santacana, J. and Serrat, N. El patrimonio arqueológico de la Guerra Civil en Cataluña. Apuntes de Arqueología 10 (2002): ii-iv. (In: Boletín del Ilustre Colegio de Doctores y Licenciados, 14-16).

Besolí, A. Fernández, M. and Tatjer, M. Ingeniería civil para la guerra, patrimonio para edificar la paz: el caso de los refugios antiaéreos de Barcelona. Patrimonio Industrial e Historia Militar, nuevos usos en el urbanismo y la cultura. Gijón, Icuna (2006).

Boletín Fundación Andreu Nin. Orwell en Aragón. Boletín Electrónico de la Fundación Andreu Nin 53 (2006). http://www.fundanin.org/Boletin53.htm

Boraine, A. A Country Unmasked: South Africa's Truth and Reconciliation Commission. Cape Town, Oxford, Oxford University Press (2001).

Buchli, V. and Lucas, G. The absent present. Archaeologies of the contemporary past. In: Buchli, V. and G. Lucas (eds.) Archaeologies of the contemporary past, 3-18. London, New York, Routledge (2001).

Calabuig, J.A. La ruta de las trincheras de la Guerra Civil: Sarrión-Náquera. Las Provincias 15 August 2006.

Castell, E., Falcó, L., Hernández, F.X., Junqueras, O., Luque, J.C. and Santacana, J. La batalla de l'Ebre. Història, paisatge i patrimoni. Barcelona, Pòrtic (2000).

Connerton, P. Cultural memory. In: Tilley, C. W. Keane, S. Küchler, M. Rowlands and P. Spyer (eds.): Handbook of material culture. 315-324, London, New York, Sage, (2006).

Crossland, Z. Buried lives. Forensic archaeology and the disappeared in Argentina. Archaeological Dialogues 7(2) (2000): 146-159.

Dean, J. Žižek's politics. New York, Routledge (2006).

Díaz Andreu, M. Prehistoria y franquismo. In: Mora, G. \& M. Díaz-Andreu (eds.) La cristalización del pasado: génesis y desarrollo del marco institucional de la Arqueología en España, 547-552. Málaga, Universidad de Málaga (1997). 
Díaz Díaz, B., Morín, J., Barroso, R., Escolá, M., López, M., Recio, A., Pérez-Juez, A., Recio, R. and Sánchez, E.. Arqueología de la guerrilla antifranquista en Toledo. In J.R. Villa and B. Maquedano (eds.): Espacios fortificados en la Provincia de Toledo, 615-630. Toledo: Diputación Provincial (2005).

Domanska, Ewa. Toward the archaeontology of the dead body. Rethinking History 9(4) (2005) 389-413.

Elkin, M. Opening Franco's graves. The victims of Spain's fascist past are beginning to tell their stories. Archaeology September/October (2006) 38-43.

Espinosa Maestre, F. La memoria de la represión y la lucha por su reconocimiento (en torno a la creación de la comisión interministerial). Hispania Nova. Revista de Historia Contemporánea 6 (2006). http://hispanianova.rediris.es

Etxeberría, F. Panorama organizativo sobre Antropología y Patología Forense en España. Algunas propuestas para el estudio de fosas con restos humanos de la Guerra Civil española de 1936. In: La memoria de los olvidados. Un debate sobre el silencio de la represión franquista, 183-219, Valladolid, Ámbito (2004).

Etxeberría, F., Herrasti, L. \& Ortiz, J. Valdediós, la memoria recuperada. Informe relativo a los restos humanos hallados en la fosa de Valdediós (Asturias) (n.d.) http://www.sc.ehu.es/scrwwwsr/Medicina-Legal/valdedios/Intro.htm

Ferrándiz, F. The return of Civil War ghosts: The ethnography of exhumations in contemporary Spain. Anthropology Today 22(3) (2006) 7-12.

Foucault, M. Surveiller et punir. Paris, Gallimard (1975).

Fuentes, A. Exhumació i arqueologia forense. Els afusellats a Villamayor de Montes (Burgos). L'Avenç 299 (2005) 28-30.

Funari, P.P.A. Archaeology, history and historical archaeology in South America. International Journal of Historical Archaeology 1(3) (1997) 189-206.

Funari, P.P.A. and Zarankin. A. Arqueología de la represión y la resistencia en América Latina (1960-1980). Catamarca: Universidad Nacional de Catamarca / Encuentro (2006).

Gassiot, E. Arqueología forense de la Guerra Civil: justicia y memoria de la represión fascista. Mientras Tanto 97 (2005): 95-112.

Gassiot, E., Oltra, J. Sintes, E. and Steadman, D.W. Archaeology of the Spanish Civil War: Rescue of the Memory and Historic Justice. In: Hamilakis. Y. and P. Duke (eds.) Archaeology and Capitalism: From Ethics to Politics. London, Taylor \& Francis (2006). 
Gavilán, E.. De la imposibilidad y necesidad de la "memoria histórica". In E. Silva, A. Esteban, J. Castán and P. Salvador (eds.): La memoria de los olvidados. Un debate sobre el silencio de la represión franquista, 55-65. Valladolid, Ámbito (2004).

González-Ruibal, A. The need for a decaying past. An archaeology of oblivion in Galicia (NW Spain). Home Cultures 2(2) (2005): 129-152.

Hall, M. Identity, memory and countermemory. Journal of Material Culture 11(1/2) (2006): 189-209.

Holtorf, C. Can less be more? Heritage in the age of terrorism. Public Archaeology 5(2006): 101-109.

Íñiguez, D. and Santacana, J. Les Fosses d'Albinyana: Guerra civil 1936-1939. Calafell, Llibres de Matrícula (2003).

Jaskot, P.B. The architecture of oppression: the SS, forced labor and the Nazi monumental building economy. London, New York, Routledge (2000).

Juliá, S. (ed.) Víctimas de la Guerra Civil. Madrid: Temas de Hoy (1999).

Junquera, N. La memoria de un niño al que nunca preguntaron. El País 4 November 2006.

Klausmeier, A. and Schmidt, L. Wall remnants - Wall traces. Berlin, Bonn, WestkreuzVerlag (2004)

Koshar, R. From Monuments to Traces: Artifacts of German Memory, 1870-1990. Berkeley: University of California Press (2000).

Laffin, J. Digging up the Diggers' war. Australian battlefield archaeology. Kenthurst, Kangaroo (1993).

Lafuente, I. Esclavos por la patria. La explotación de los presos bajo el franquismo. Madrid, Temas de Hoy (2002).

Latour, B. From Realpolitik to Dingpolitik—or How to make things public. In: Latour B. and P. Weibel (eds.): Making things public. Atmospheres of democracy. Cambridge: ZKM Center for Art and Media (2005).

López, L., Aldecoa, A., Obregón, T., Ortiz, J.R., Pastor, E.J., Sánchez, A.J. and Adán, M.J. Estructuras militares de la guerra civil española (1936-1939) en los municipios de Seseña y Borox (provincia de Toledo). In: Villa, J.R. and B. Maquedano (eds.): Espacios fortificados en la Provincia de Toledo, 595-614. Toledo: Diputación Provincial (2005). 
López Gómez, J.M. Un modelo de arquitectura y urbanismo franquista en Aragón: la Dirección General de Regiones Devastadas, 1939-1957. Zaragoza, Departamento de Educación y Cultura (1995).

Meskell, L. Negative heritage and past mastering in archaeology. Anthropological Quarterly 75(3) (2002) 557-574.

Mir, C., Calvet, J. \& Sagues, J. Historia, patrimonio y territorio: políticas públicas de memoria en el frente del Segre y la frontera pirenaica catalana. Hispania Nova. Revista de Historia Contemporánea 6 (2006). http://www.hispanianova.rediris.es

Molinero, C., Sala, M., \& Sobrequés, J. Una inmensa prisión: los campos de concentración y las prisiones durante la guerra civil y el franquismo. Barcelona, Crítica (2003).

Montaner, R. Amparo Salvador: 'El PP quiere mantener las fosas en la clandestinidad'. Levante 15 May 2006.

Montero Barrado, S. Paisajes de la Guerra. Nueve itinerarios por los frentes de Madrid. Madrid, Comunidad de Madrid, 1987.

Montero Barrado, S. Arqueología de la Guerra Civil en Madrid. Historia y Comunicación Social 6 (2001): 97-122.

Morín de Pablos, J. El yacimiento de Casas de Murcia (Villa de Vallecas). Excavaciones arqueológicas en un fortín republicano en la segunda línea de defensa de Madrid capital. Militaria. Revista de Cultura Militar 16 (2002) 139164.

Morín de Pablos, J., Díaz, B., Barroso, R., Escolá, M., López, M., Pérez-Juez, A., Recio, A. and Sánchez, F. Arqueología de la guerrilla antifranquista en Toledo. La $14^{\mathrm{a}}$. División de la $1^{\mathrm{a}}$. Agrupación del Ejército de Extremadura y Centro. Bolskan 21 (2006) 181-188.

Nicieza, I. Alertan de la desaparición del patrimonio histórico de la Guerra Civil. La Nueva España 12 December 2006.

Nora, P. Entre mémoire et histoire. La problématique des lieux. In: Nora, P. (ed.) Les lieux de mémoire. I. La République, xv-xlii. Paris, Gallimard (1984).

Núñez Díaz-Balart, M. Los años del terror: la estrategia de dominio y represión del general Franco. Madrid, La Esfera de los Libros (2004).

Olaizola, J. Trabajo forzado y ferrocarril. Destacamentos penales y construcción de infraestructuras ferroviarias. IV Congreso de Historia Ferroviaria. Málaga, 1-28 (2006). 
Olivier, L. The archaeology of the contemporary past. In: Buchli, V. and G. Lucas (eds.) Archaeologies of the contemporary past, 175-188. London, New York, Routledge (2001).

Payne, S. Spain's first democracy: the Second Republic 1931-1936. Madison, University of Wisconsin Press (1993).

Pérez-Juez, A., Morín, J., Barroso, R., Escolà, M. Arqueología de la Guerra Civil: Excavaciones arqueológicas en las trincheras. Revista de Arqueología 250 (2002) 22-31.

Pérez-Juez, A., Morín, J., Barroso, R., Escolà, M., Agustí, E, Sánchez, F. El patrimonio arqueológico de la Guerra Civil española: la necesidad de su conservación como testimonio de una época. Patina 12 (2004) 125-133.

Piñera, L.M. Los refugios gijoneses durante la Guerra Civil. Patrimonio Industrial e Historia Militar, nuevos usos en el urbanismo y la cultura. Gijón, Icuna (2006).

Pi-Sunyer, O. Ghosts and memories. A response to Ferrándiz. Anthropology Today 22(6) (2006) 24.

Pizzi, D. Città metafisiche: città di fondazione dall'Italia all'oltremare 1920-1945. Milan, Skira (2005).

Price, J. Orphan heritage. Issues in managing the heritage of the Great War in northern France and Belgium. Journal of Conflict Archaeology 1 (2005) 181-196.

Reig Tapia, A. Memoria de la Guerra Civil. Los mitos de la tribu. Madrid, Alianza (1999).

Renshaw, L. The iconography of exhumation: representations of mass graves from the Spanish Civil War. In Clack, T. and M. Brittain (eds.): Archaeology and the media. Walnut Creek, CA: Left Coast Press, in press (2007).

Rodrigo, J. Cautivos: campos de concentración en la España franquista, 1936-1947. Barcelona, Crítica (2005).

Rodríguez, D. El gobierno retira la estatua de Franco en Nuevos Ministerios. El Mundo, 17 March 2005.

Romero, E. Itinerarios de la Guerra Civil Española. Barcelona, Laertes (2001).

Romero, E. La Guerra Civil en Cataluña y los caminos de la memoria. Ebre 382 (2003) 77-92.

Ruiz, A., Sánchez, A. \& Bellón, J.P. The history of the Iberian archaeology: one archaeology for two Spains. Antiquity 76 (2002) 184-190. 
Ruiz Zapatero, G. and Álvarez-Sanchís, J.R. España y los españoles hace dos mil años según el bachillerato franquista (período 1936-1953). Iberia. Revista de la Antigüedad 1 (1998): 37-52.

Santacana, J. Entre l'oblit i la memória. El patrimoni de la guerra. Ebre 382 (2004) 169-179.

Saunders, N.J. Excavating memories: archaeology and the Great War, 1914-2001. Antiquity 70 (2002) 401-408.

Schofield, J. 2005. Combat archaeology. Material culture and modern conflict. London: Duckworth.

Shanks, M. Culture/Archaeology. In I. Hodder (ed.): Archaeological theory today, 284305. Cambridge, Oxford, Polity (2001).

Shanks, M. Archaeology/Politics. In: Bintliff, J. (ed.) A companion to archaeology. Oxford, Blackwell (2004).

Silva, E. and Macías, S. Las fosas de Franco: los republicanos que el dictador dejó en las cunetas. Madrid, Temas de Hoy (2006).

Sontag, Susan. Regarding the pain of others. New York, Picador (2003).

Sutherland, T. and Holst, M. Battlefield Archaeology - A Guide to the Archaeology of Conflict. London, British Archaeological Jobs Resource (2005).

Tarlow, S. and West, S. (eds.) The familiar past?: archaeologies of later historical Britain. London, New York, Routledge (1999).

Thomas, H. La Guerra Civil Española. Madrid, Grijalbo (1976).

Thomas, H. The Spanish Civil War. New York, Modern Library (2001).

Tremlett, G. Ghosts of Spain. Travels through a country hidden past. London, Faber \& Faber (2006).

Valdeón Baruque, J. El archivo de Salamanca debería convertirse en el archivo de la Guerra Civil. Aranzadiana 125 (2004) 106-108

Virilio, P. and Lotringer, S. Pure war. New York, Semiotext(e) (1997).

Visa, L. Ayuntamientos del Pirineo recuperan la memoria de la Guerra Civil. El País, 26 August 2006.

Witmore, C. Landscape, time, topology: An archaeological account of the southern Argolid Greece. In Hicks, D., G. Fairclough and L. McAtackney (eds.) Landscapes in Archaeology. One World Archaeology, in press (2007). 


\section{CAPTIONS}

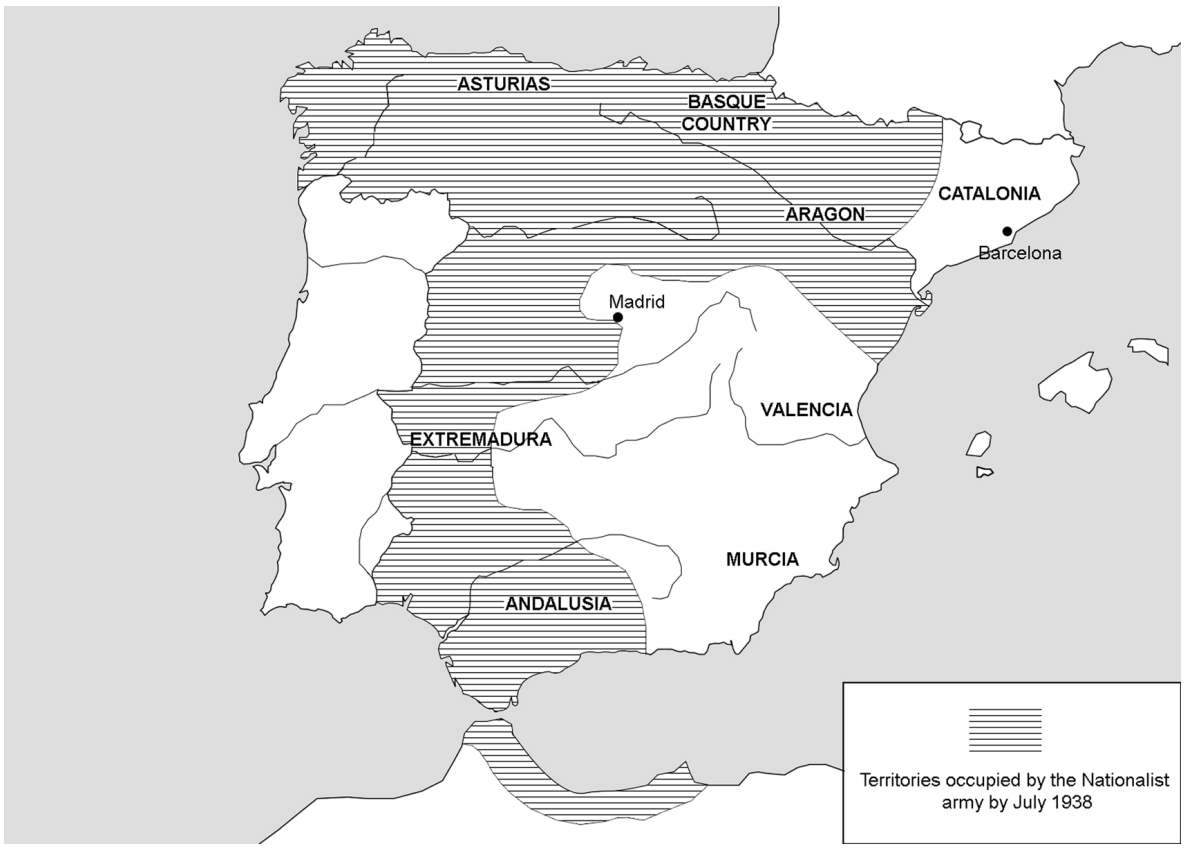

Figure 1. The frontline in 1938 with places mentioned in the article.

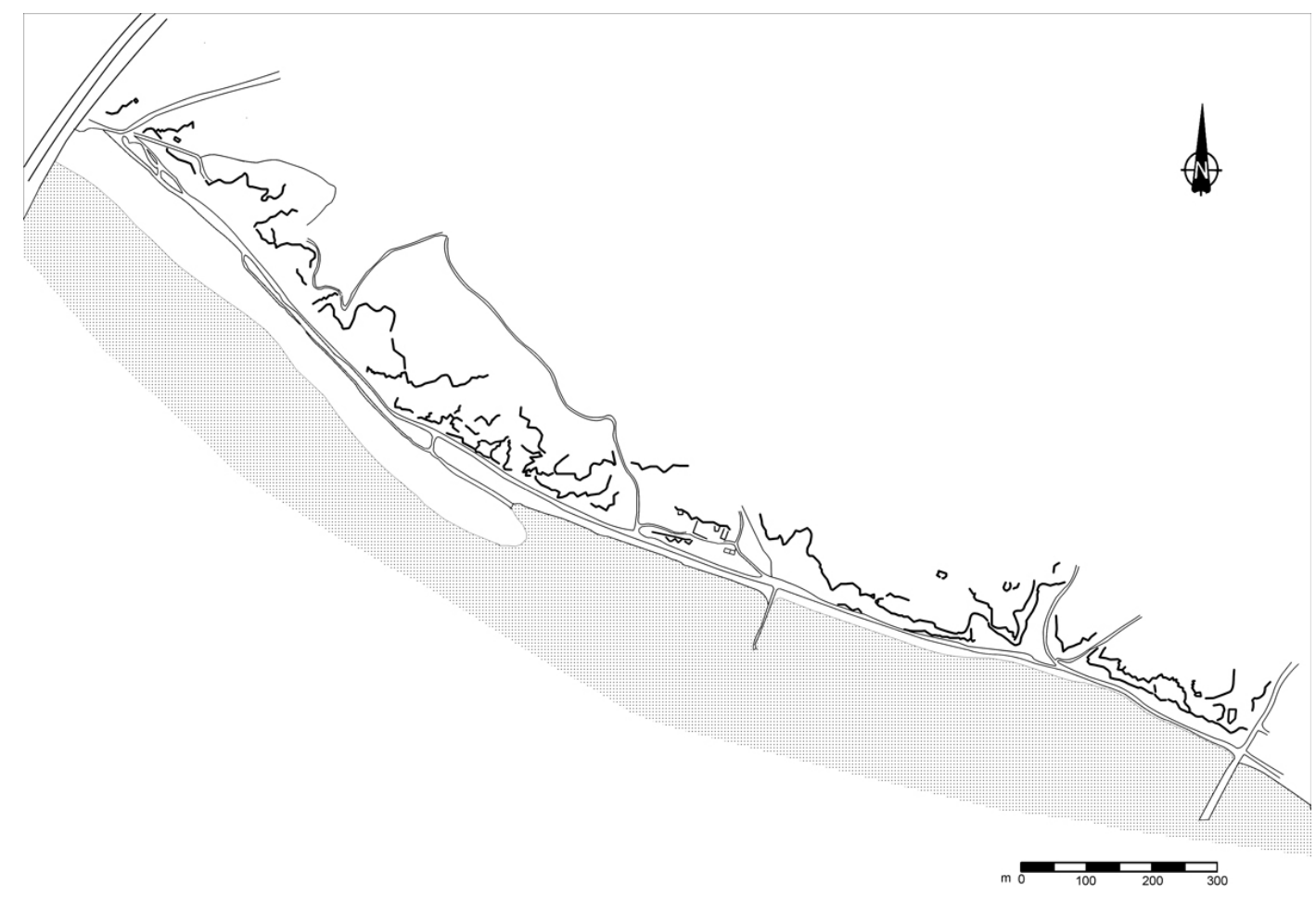

Figure 2. Republican trenches along the Manzanares River (Madrid). 


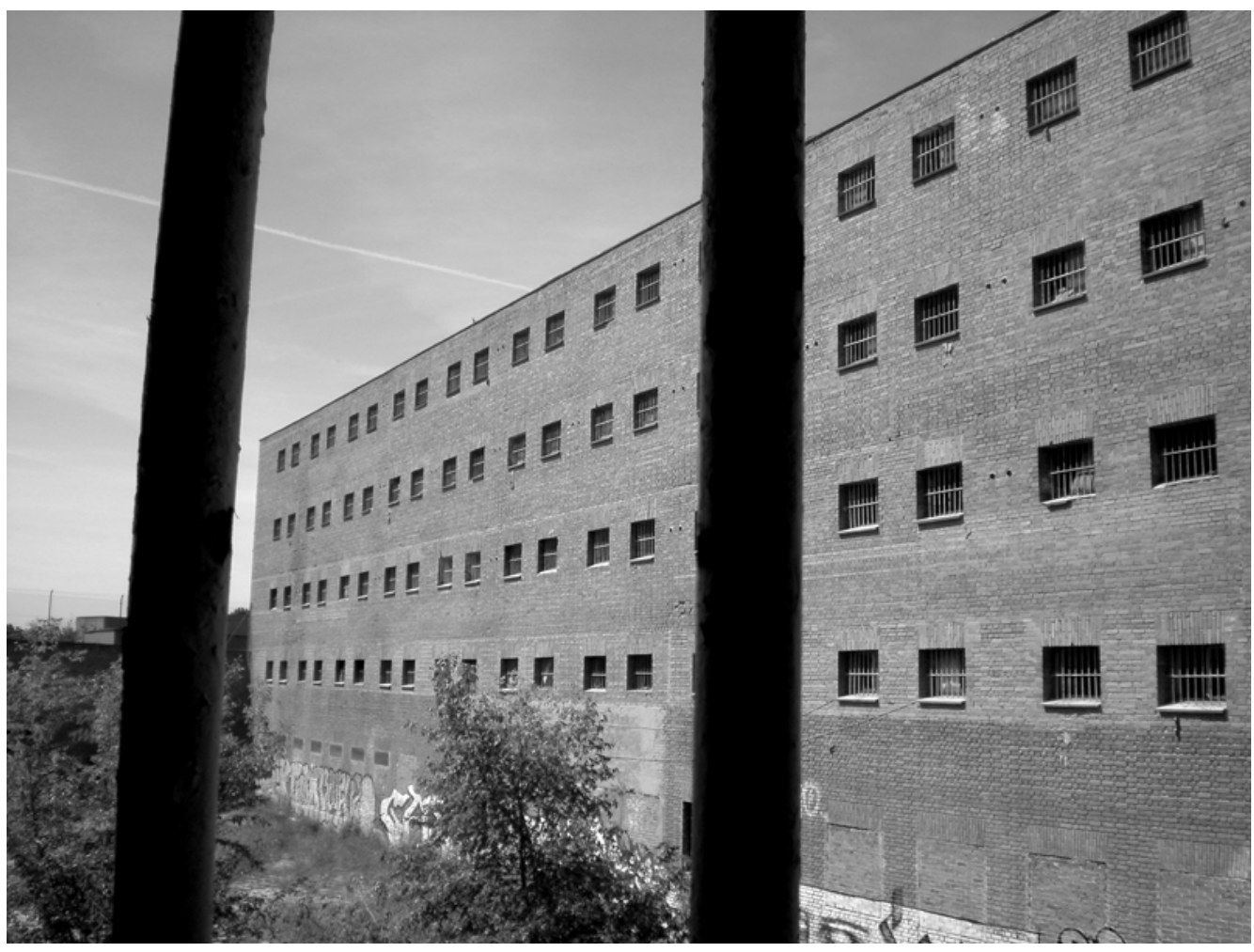

Figure 3. The ruined prison of Carabanchel (Madrid), built in 1940.

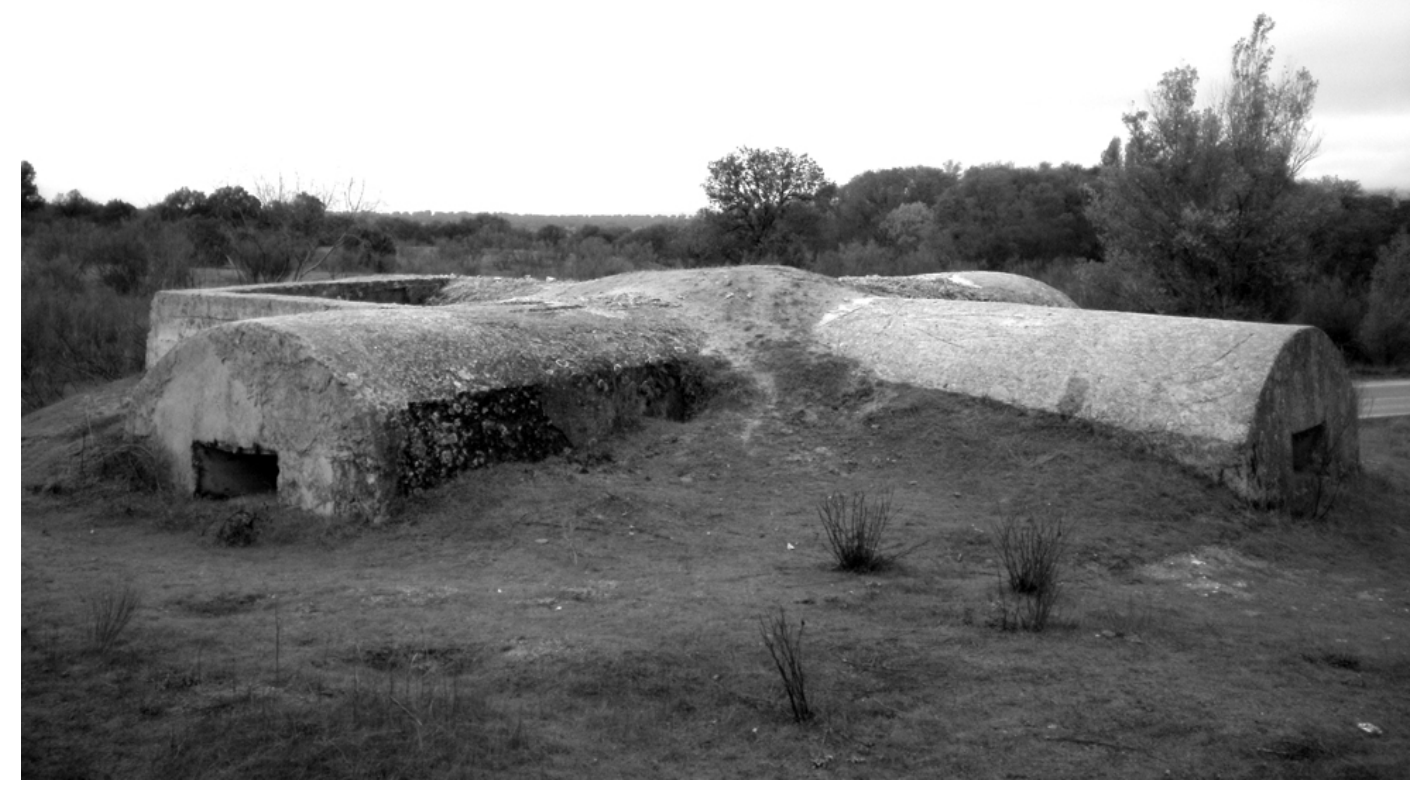

Figure 4. One of the many bunkers from the Civil War surviving in Spain (Brunete, Madrid). 

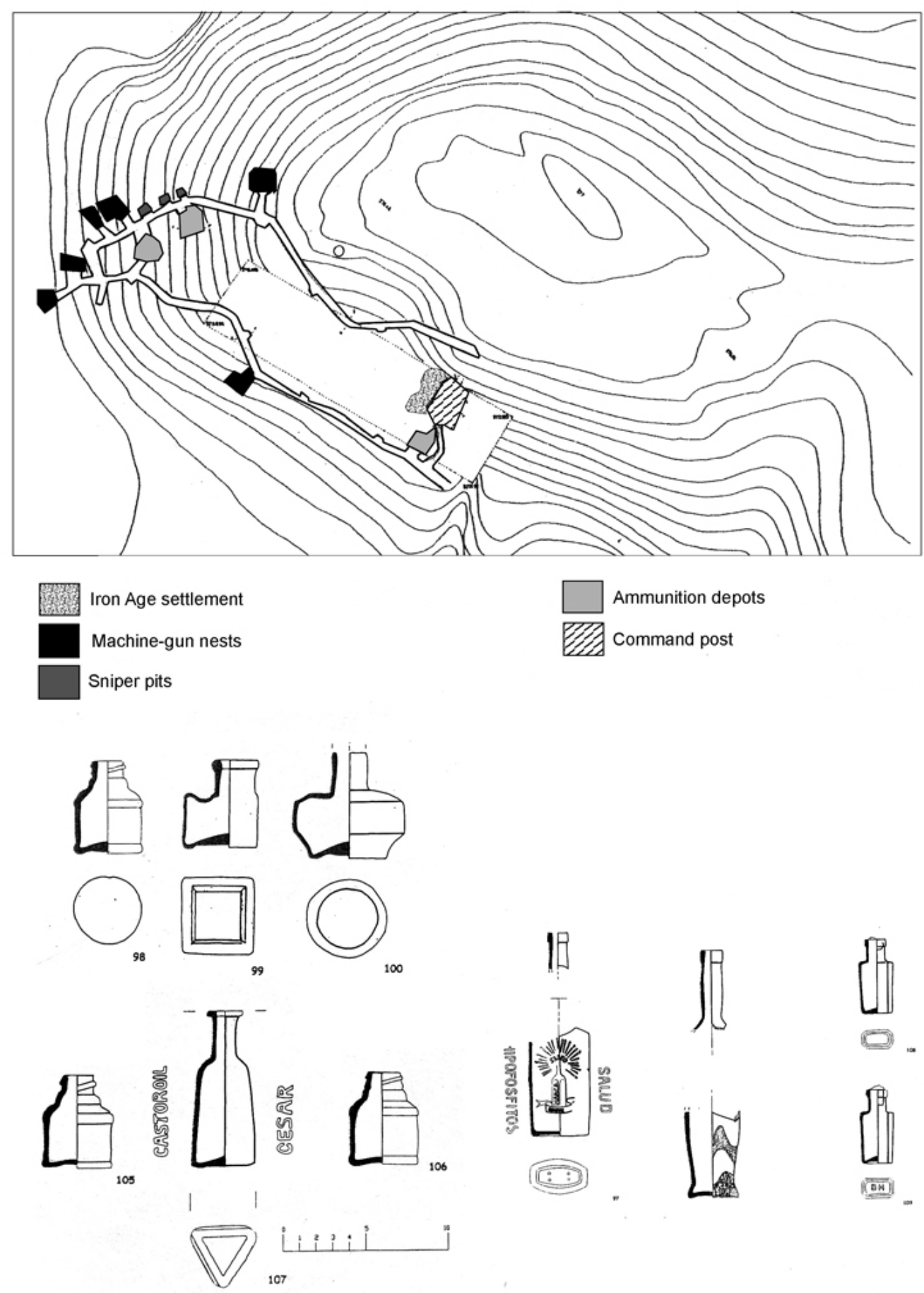

Figure 5. Map of the Republican fort of Cerro de la Gavia (Madrid) and associated finds (redrawn after Morín et al. 2005). 


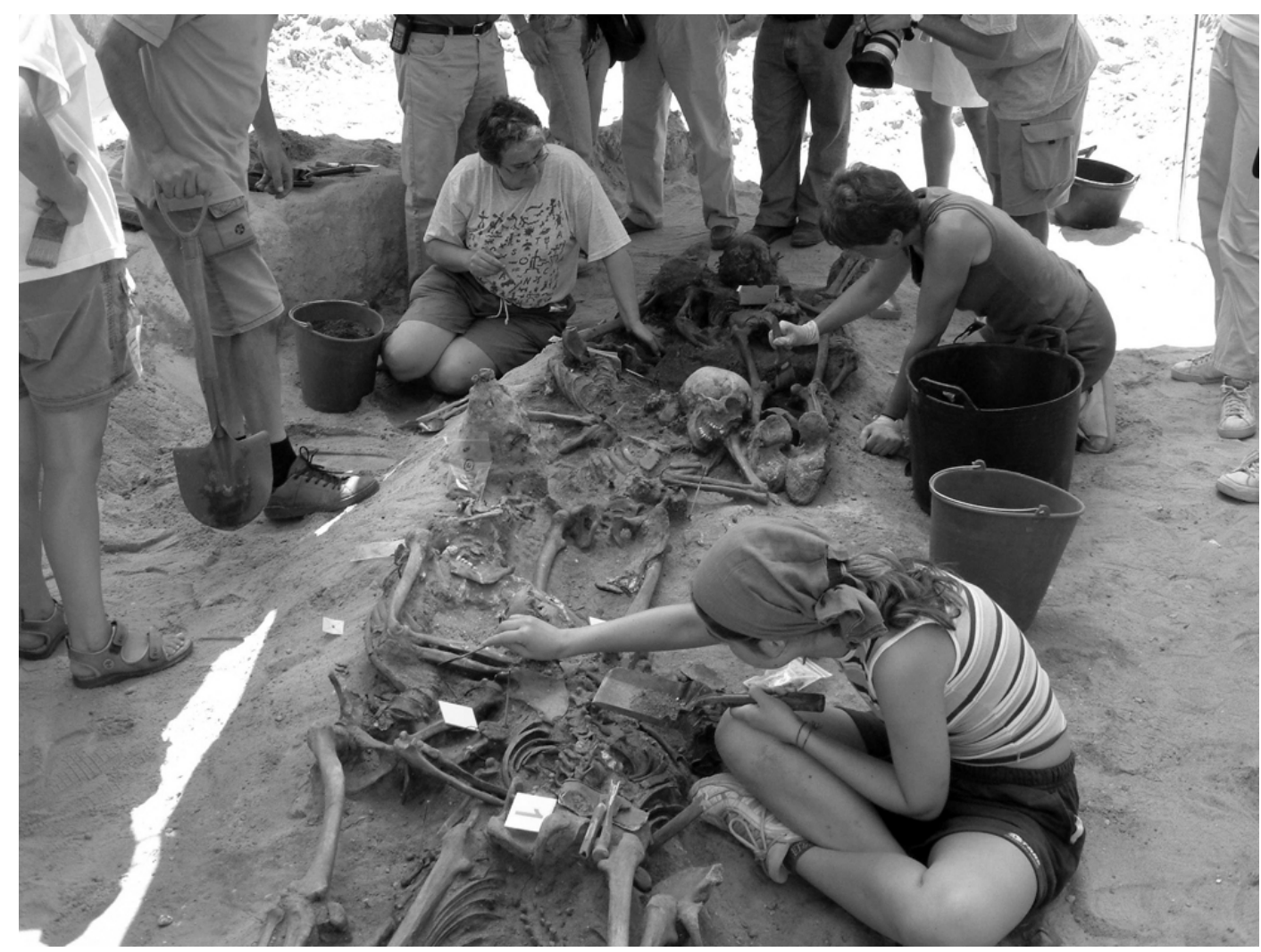

Figure 6. A mass grave excavated by the Asociación por la Recuperación de la Memoria Histórica in Olmedillo de Roa (Burgos).

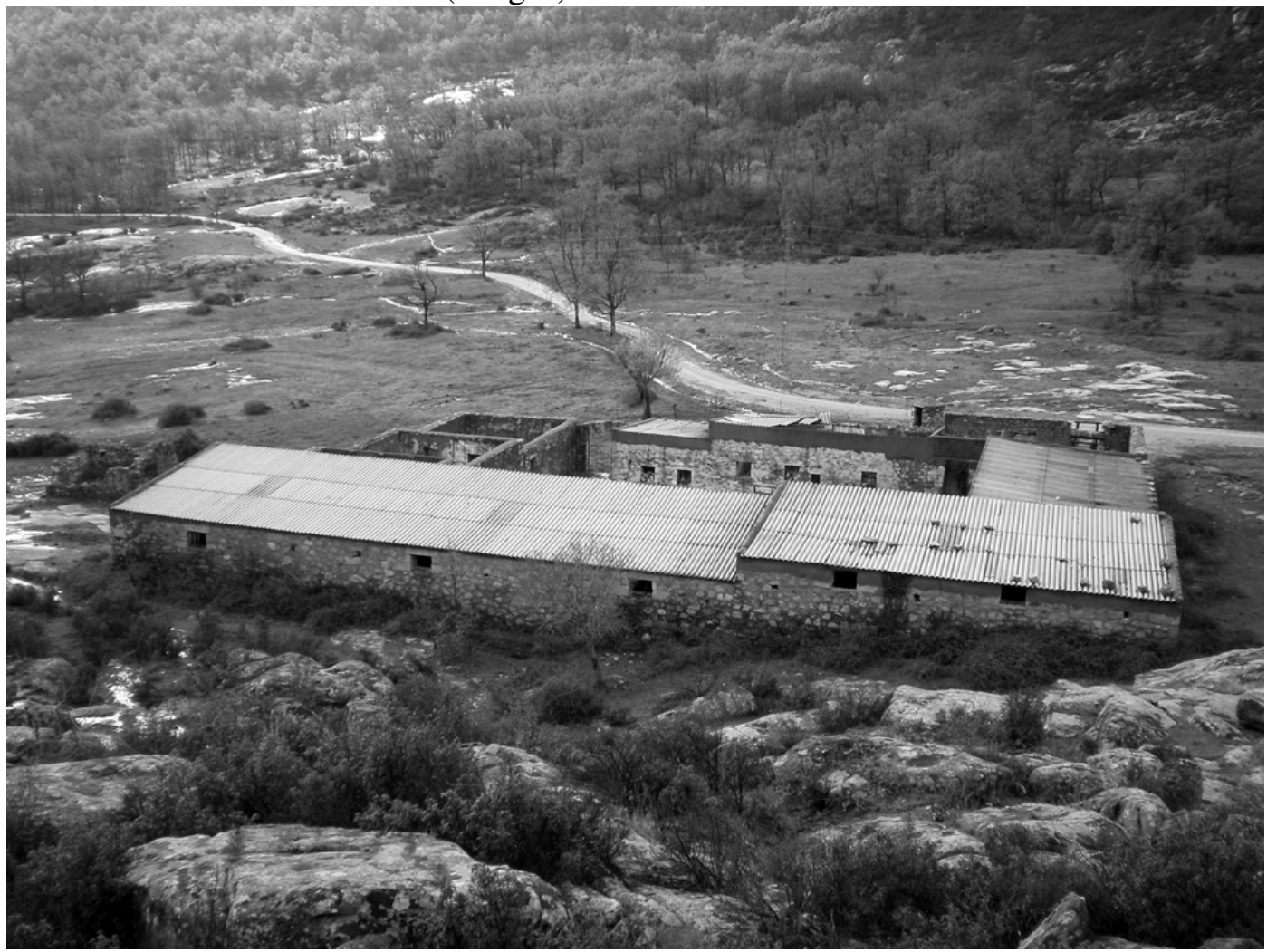

Figure 7. The concentration camp of Bustarviejo (Madrid). 


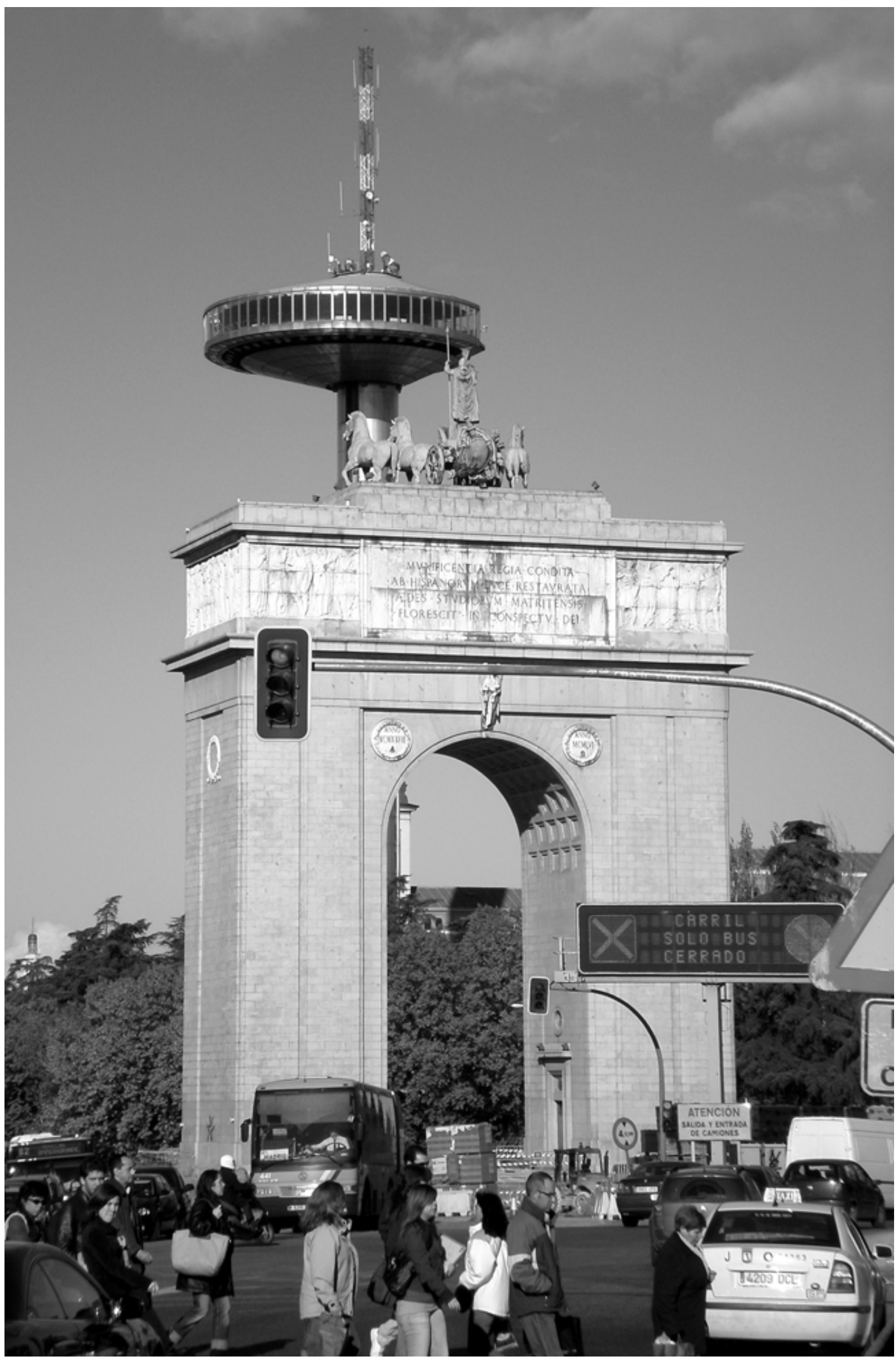

Figure 8. The triumphal arch built by Franco in 1964 for the commemoration of the 25th anniversary of his victory, still presiding over the entrance of Madrid. 


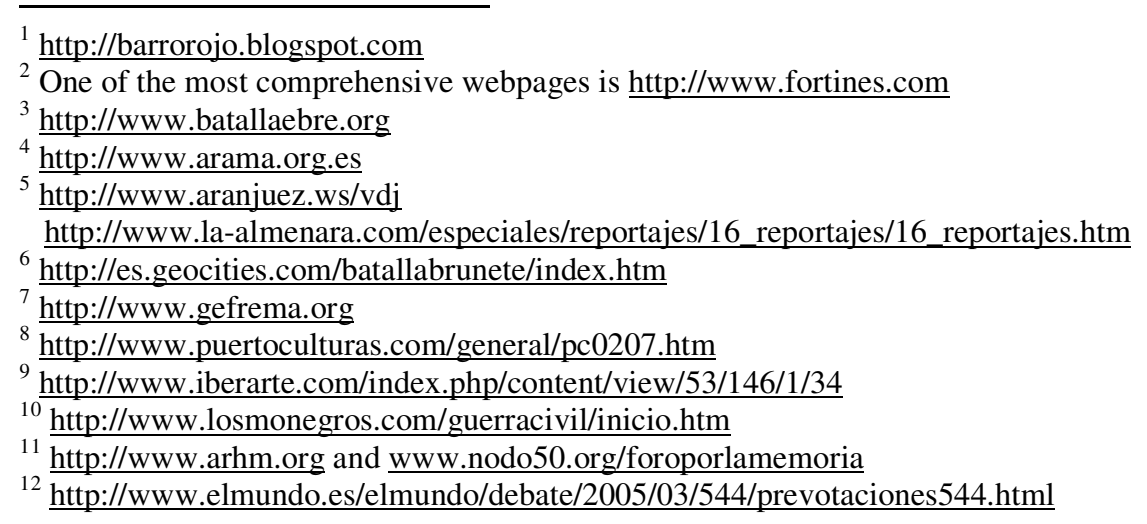

